\title{
Increased percentages of calprotectin and TNF-A double-positive monocytes in the acute phase of Kawasaki disease
}

\author{
Rolando Cimaz ${ }^{1 *}$, Giuliana Guggino ${ }^{2}$, Salvatore Accomando², Gabriele Simonini', Ilaria Pagnini ${ }^{1}, E_{i j i}$ Ohtsu ${ }^{3}$, \\ Tomisaku Kawasaki ${ }^{3}$, Francesco Dieli ${ }^{2}$, Mahavir Singh ${ }^{4}$, Guido Sireci ${ }^{2}$
}

From 18th Pediatric Rheumatology European Society (PReS) Congress

Bruges, Belgium. 14-18 September 2011

\section{Background}

The acute phase of KD is characterized by a deficiency of suppressor $\mathrm{T}$ cells, marked activation of the immune system and increased secretion of cytokines by immune effector cells. Moreover, it has been shown that myeloid-related protein (MRP-8 and MRP-14) and S100proteins, the major calcium-binding proteins secreted by activated neutrophils and monocytes, contribute to cause inflammation in acute lesions of $\mathrm{KD}$, and indeed one of the more common hematological alteration in $\mathrm{KD}$ is the increase of peripheral blood monocytes. Calprotectin, one of the major calcium-binding proteins, can lead to direct and indirect effects that result not only in inflammation but also in modification of microvascular wall in acute vasculitis syndromes.

\section{Aim}

To study the percentages of "polyfunctional monocytes", after in vitro exposure to several peptides, as a novel immune correlate of inflammation and endothelial damage mainly occurring in the acute phase of KD.

\section{Methods}

We have analyzed the in vitro response of Periperal Blood Mononuclear Cells (PBMCs) to different peptides, i.e. p28, peptide \#1, peptide \#4 (gpm1 like-molecules derived from S. sanguinis) and peptide \#42 (chain A, solution structure of human complement factor $\mathrm{H}$ ) that could play a critical role in the inflammation of acute phase of KD. We assessed the production of Calprotectin and Tumor Necrosis Factor (TNF)- $\alpha$ in CD14 ${ }^{+}$cells, that might be involved in the endothelial damage. Intracellular Calprotectin was evaluated after stimulation in $\mathrm{CD} 14^{+}$cells in patients with acute KD and in age- and sex-matched acute febrile controls. We have enrolled 8 children (5M, 3F, age range 4 months- 3 years) affected by Kawasaki disease with cardiac involvement. Only three of them improved with a single cycle of intravenous immunoglobulins, while four needed a second cycle and one also needed intravenous corticosteroids and Infliximab. PBMCs were cultured with selected peptides and cells were fixed, permeabilized, and then stained with anti-human calprotectin-FITC and antihuman TNF- $\alpha$-PE.

\section{Results}

Patients with acute KD had increased percentages of intracellular Calprotectin in $\mathrm{CD}_{1} 4^{+}$when stimulated with antigens. On the contrary, age-matched febrile controls did not show any increase of intracellular Calprotectin in $\mathrm{CD} 14^{+}$cells after stimulation. The only one patient with acute KD who did not show any increase of intracellular Calprotectin in $\mathrm{CD}_{1}{ }^{+}$cells was the one resistant to traditional therapy and who was subsequently treated with an anti-TNF- $\alpha$ antibody. Additionally, statistically significant higher percentages of double TNF- $\alpha^{+}$Calprotectin ${ }^{+}$CD $14^{+}$were observed $(\mathrm{p}<0.05)$, in PBMCs of patients when compared to febrile controls

\section{Conclusion}

"Polyfunctional monocytes" could represent an important cell subset involved in the generation of acute KD. 


\section{Author details}

${ }^{1} \mathrm{AOU}$ Meyer Firenze Italy. ${ }^{2}$ Università di Palermo, Italy. ${ }^{3}$ Kawasaki Disease Research Center, Tokyo, Japan. ${ }^{4}$ LIONEX Diagnostics \& Therapeutics,

Braunschweig, Germany.

Published: 14 September 2011

doi:10.1186/1546-0096-9-S1-013

Cite this article as: Cimaz et al.: Increased percentages of calprotectin and TNF-A double-positive monocytes in the acute phase of Kawasaki disease. Pediatric Rheumatology 2011 9(Suppl 1):013.

Submit your next manuscript to BioMed Central and take full advantage of:

- Convenient online submission

- Thorough peer review

- No space constraints or color figure charges

- Immediate publication on acceptance

- Inclusion in PubMed, CAS, Scopus and Google Scholar

- Research which is freely available for redistribution

Submit your manuscript at www.biomedcentral.com/submit

() BioMed Central 